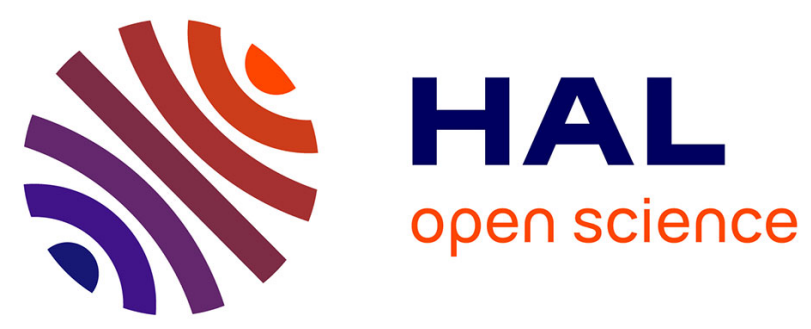

\title{
Axillary lymph node dissection in early-stage invasive breast cancer: is it still standard today?
}

Bernd Gerber, Kristin Heintze, Johannes Stubert, Max Dieterich, Steffi Hartmann, Angrit Stachs, Toralf Reimer

\section{- To cite this version:}

Bernd Gerber, Kristin Heintze, Johannes Stubert, Max Dieterich, Steffi Hartmann, et al.. Axillary lymph node dissection in early-stage invasive breast cancer: is it still standard today?. Breast Cancer Research and Treatment, 2011, 128 (3), pp.613-624. 10.1007/s10549-011-1532-0 . hal-00636203

\section{HAL Id: hal-00636203 https://hal.science/hal-00636203}

Submitted on 27 Oct 2011

HAL is a multi-disciplinary open access archive for the deposit and dissemination of scientific research documents, whether they are published or not. The documents may come from teaching and research institutions in France or abroad, or from public or private research centers.
L'archive ouverte pluridisciplinaire HAL, est destinée au dépôt et à la diffusion de documents scientifiques de niveau recherche, publiés ou non, émanant des établissements d'enseignement et de recherche français ou étrangers, des laboratoires publics ou privés. 
Axillary lymph node dissection in early-stage invasive breast cancer: Is it still standard today?

Bernd Gerber, Kristin Heintze, Johannes Stubert, Max Dieterich, Steffi Hartmann, Angrit Stachs, Toralf Reimer

Department of Obstetrics and Gynecology, University of Rostock, Suedring 81, 18059 Rostock, Germany

Correspondence Address:

Bernd Gerber, MD, PhD

Department of Obstetrics and Gynecology, University of Rostock, Suedring 81, 18059 Rostock, Germany

e-mail: bernd.gerber@med.uni-rostock.de

Tel: +49 / 381 / 4401-4500

Fax: +49 / $381 / 4401-4599$

Short running head: Axillary lymph node extirpation in early breast cancer

Key words: breast cancer, axillary lymph nodes, dissection, sentinel, prognosis, metastases 
Responsibilities:

\begin{tabular}{|l|l|}
\hline Bernd Gerber & idea, literature search, writing, coordination \\
\hline Kristin Heintze & $\begin{array}{l}\text { literature search, writing, macrometastases } \\
\text { and In which patient is axillary surgery } \\
\text { avoidable? }\end{array}$ \\
\hline Johannes Stubert & $\begin{array}{l}\text { literature search, writing tumor biology and } \\
\text { do lymph node metastases metastasize? }\end{array}$ \\
\hline Max Dieterich & literature search, writing micrometastases \\
\hline Steffi Hartmann & $\begin{array}{l}\text { literature search, writing non-invasive } \\
\text { diagnostics }\end{array}$ \\
\hline Angrit Stachs & $\begin{array}{l}\text { literature search, writing non-invasive } \\
\text { diagnostics }\end{array}$ \\
\hline Toralf Reimer & $\begin{array}{l}\text { literature search, reviewing, writing, } \\
\text { coordination }\end{array}$ \\
\hline
\end{tabular}




\section{Abstract}

Evaluation of axillary lymph node status by sentinel lymph node biopsy (SLNB) and complete axillary lymph node dissection (ALND) are an inherent part of breast cancer treatment. Increased understanding of tumor biology has changed the prognostic and therapeutic impact of lymph node status. Non-invasive imaging techniques like axillary ultrasound, FDG-PET or MRI revealed moderate sensitivity and high specificity in evaluation of lymph node status. Therefore, they are not sufficient for lymph node staging. Otherwise the impact of remaining micrometastases and even macrometastases for prognosis and treatment decisions is overestimated. Considering tumor biology, the distinction of axillary metastases in isolated tumor cells (ITC, pNO[i+]); micrometastases (pN1mi), and macrometastases (pN1a) is not comprehensible. Increasing data support the thesis that remaining axillary metastases neither increase the axillary recurrence rate nor decrease overall survival. It is doubtful that axillary tumor cells are capable to complete the complex multistep metastatic process. If applied, axillary metastases are sensitive to systemic treatment and are targeted by postoperative tangential breast irradiation. Therefore, the controversy about the clinical relevance of tumor cell clusters or micrometastases in SLN is a sophisticated but not contemporary discussion. Currently, there is no indication for axillary surgery in elderly patients with favorable tumors and clinically tumor-free lymph nodes. Nonetheless, a rational and evidence-based approach to the management of clinically and sonographically NO patients with planned breastconserving surgery and limited tumor size is needed now. 


\section{Introduction}

The axillary lymph node dissection (ALND) with removal and histopathological examination of at least 10 nodes was an inherent part of surgical treatment of breast cancer for a considerable time. During the last decade ALND was replaced by sentinel lymph node biopsy (SLNB) in patients with clinically and sonographically unsuspicious lymph nodes [1-3]. As a consequence the arm morbidity was reduced markedly [4]. The SLNB requires estimated costs of 200-250€ per sentinel labeling and $1,750 €$ per axillary surgery (Webgrouper DRG Research Group, University of Muenster, Germany). Due to nationwide mammography screening in most industrial countries, a greater number of smaller tumors without axillary lymph node involvement is detected. More than $60 \%$ of all primary operable breast cancers do not have axillary lymph node metastases. This in turn means that even SLNB represents an overtreatment and is not indicated in the majority of patients. Noninvasive methods like ultrasound, fluorodeoxyglucose positron emission tomography (FDG-PET), and magnetic resonance imaging (MRI), have gained more importance in staging the axillary lymph nodes. With improved insight into primary tumor biology and metastasis behavior, the relevance of nodal status for adjuvant treatment decisions is decreasing. Currently, in cases with positive sentinel lymph nodes (SLN) the need for completion ALND is arguable. Nevertheless, there is an ongoing discussion about the prognostic impact of isolated tumor cells (ITC, pNO(i+); $\leq 0.2$ $\mathrm{mm}$ ), micrometastases ( $\mathrm{pN} 1 \mathrm{mi} ;>0.2 \mathrm{~mm}$ to $\leq 2.0 \mathrm{~mm}$ ), and macrometastases ( $\mathrm{pN} 1 \mathrm{a}$; $>2.0 \mathrm{~mm}$ ) in SLNs. The aim of this review was firstly to assess the imaging techniques in axillary lymph node staging and secondly to evaluate the impact of pathological lymph node status regarding prognosis and treatment decisions. The key question to be answered is: Is there a chance to avoid axillary lymph node 
surgery in patients with early breast cancer? This review is not covering the issue of axillary surgery following primary systemic treatment.

\section{Materials and methods}

We performed a selective literature search on PubMed database using the search terms "breast cancer \& axillary lymph nodes" and "ultrasound or sonography", "MRl" or "PET" and "sentinel lymph node and micrometastases" for the period from January 2002 to February 2011. Activated limits for search were "Female, Clinical Trial, MetaAnalysis, Randomized Controlled Trial, English". Contributions to international congresses on breast cancer in 2009 (SABCS, San Antonio Breast Cancer Symposium; ECCO, European Cancer Organization; EBCC, European Breast Cancer Conference) and 2010 (ASCO, American Society of Clinical Oncology) were included. The treatment recommendations of AGO-Mamma (the Breast Group of the

German Gynecological Oncology Working Group [5]) and the NCCN (National Comprehensive Cancer Network) Guidelines [6] together with the Cochrane Library [7] were also considered.

\section{Imaging techniques}

The exclusion of lymph node metastases by using non-invasive methods could reduce the rate of axillary surgery. However, the experience of examiner and period of availability are crucial for the diagnostic precision and prediction.

Axillary Ultrasound (AUS)

Clinically palpable axillary nodes are widely considered as contraindication to SLNB in breast cancer. However, various studies have shown that clinical assessment of axillary lymph nodes alone is inaccurate with a false-positive rate up to $40 \%[8,9]$. 
Among patients with clinically uninvolved axillary lymph nodes, AUS has additional value in detecting pathological axillary nodes $[10,11]$. One third of pathological involved lymph nodes could predicted preoperatively by ultrasound. AUS combined with fine needle aspiration (FNA) biopsy of suspicious nodes has shown useful results to guide preoperative surgical planning $[12,13]$. However, the reported sensitivity for AUS-FNA has varied considerably between different studies [14, 15]. Because of the risk of false-negative results, negative FNA findings are almost followed by SLNB for confirmation.

According to guidelines, a SLNB is only indicated in patients with histologically proven invasive breast cancer and clinically and sonographically insuspect lymph nodes. In a systematic review including 16 studies, in which AUS without palpable lymph nodes was performed, the node size and the morphology were used as criteria for positivity [15]. For lymph node size sensitivity varied between $48.8 \%$ (95\% confidence interval [Cl]: 39.6-58\%) and $87.1 \%$ (76.1-94.3\%) and specificity, between $55.6 \%(44.7-66.3 \%)$ and $97.3 \%$ (86.1-99.9\%). If lymph node morphology was used as the criterion for positivity, sensitivity ranged from $26.4 \%(15.3-40.3 \%)$ to $75.9 \%$ (56.4-89.7\%) and specificity, from $88.4 \%$ (82.1-93.1\%) to $98.1 \%$ (90.1-99.9\%). After sonographically guided node biopsy, sensitivity varied between 30.6\% (22.5-39.6\%) and $62.9 \%(49.7-74.8 \%)$ and specificity was nearly $100 \%$ (94.8-100\%). More recent studies confirmed these percentage rates for AUS-FNA showing sensitivities from $53 \%$ to $59 \%$ and specificities of $100 \%[16,17]$. AUS-FNA seems to be most useful in the preoperative assessment of patients with large breast tumors $(>2 \mathrm{~cm})$ or with lymph nodes that appear abnormal.

In conclusion, AUS is moderately sensitive and fairly specific in the diagnosis of axillary metastatic involvement. These scattered variabilities are the result of the missing clear criteria for evaluation of axillary lymph nodes by ultrasound. The 
classification of axillary lymph nodes on the basis of cortical thickness (cut-off 2.5 $\mathrm{mm}$ ) and the appearance of the fatty hilum on sonography was effective for predicting the presences of metastases in a recent study [18]. In future, addition of contrast-enhanced color and power doppler ultrasound may improve the sensitivity of AUS [19]. Malignant lymph nodes showed longer contrast enhancement duration compared to benign lymph nodes.

\section{FDG-PET}

FDG-PET seemed to be an interesting approach as a non-invasive method of staging the axilla in breast cancer patients. In a meta-analysis, 21 studies for clinical use of FDG-PET in investigating axillary nodes were graded on methodological quality of the single studies depending on number and selection of patients, technical details of examination, pro- or retrospective design, and kind of lymph node biopsy [20]. As shown in table 1 best quality studies showed a sensitivity, specificity, positive and negative predictive value of around $80 \%$, whereas in the poorer quality studies the diagnostic accuracy was higher. However, the variability between study designs has made it difficult to compare and aggregate the results of these studies. As well, caution must be exercised when analyzing results from older studies because of the increased accuracy of the newer scanners [20].

In a current meta-analysis of 25 studies including 2,460 patients a trend to lower sensitivity (37-85\%) in the most recent published and higher quality studies (year 2005-2009 and sample size $\geq 25$ ) was detectable, whereas the specificity $(84-100 \%)$ remained high [21]. This meta-analysis also indicated that the sensitivity of PET is not sufficient to detect small metastatic deposits (micrometastases). Interestingly, the metabolic activity is variable according to the histopathological subtype of breast cancer. The mean tumor maximum standardized uptake value SUV(max) in lymph 
node metastases of estrogen receptor (ER)-positive, triple-negative and human epidermal growth factor receptor 2 (HER2)-positive tumors was 6.6, 11.6, and 6.6, respectively [22].

In conclusion, sensitivity and specifity of PET is comparable to AUS, but because AUS is less expensive, AUS remains standard of care these days. The combination of AUS and PET seems to be improved the diagnostic accuracy [23]. The additional benefit of an assessment of distal metastatic spread provided by PET requires further investigation [21].

\section{MRI}

Breast MRI assessment of breast cancer patients considered for primary surgical treatment is being used more frequently, especially if breast-conserving surgery (BCS) is planned. During such assessment, regional lymph nodes are usually included. Using different contrast agents, sensitivity ranged from 63-100\% and specificity from 56-100\% (Tab. 2). Like FDG-PET, contrast-enhanced MRI accuracy showed a close relationship with histopathologic subtypes of invasive breast cancer and its limitation in detection of axillary micrometastases [29, 31, 32]. Adding axillary MRI sequentially after AUS did not significantly improve detection of positive nodes in AUS-negative cases (false-negative rate of $28 \%$ and false-positive rate of $18 \%$ for MRI) [16].

Taken together, all imaging techniques are of high specificity and moderate sensitivity especially in cases with small lymph node metastases. The value of combined imaging techniques for improving the diagnostic accuracy should be considered critically with respect to benefit-cost-ratio. 
In the following we have to discuss three fundamental questions: Firstly, is it really important to know the nodal status for treatment decisions? Secondly, is there a chance to avoid axillary surgery in some cases and how can we select these patients? And thirdly, how is the biological behavior of metastatic involved lymph nodes left in situ (separated by tumor cluster size)?

\section{Lymph node status for prognosis and treatment decision}

Since Halsted first defined the issue of axillary lymph nodes 100 years ago, the lymph node status is the basis for prognosis and treatment decision in breast cancer [33]. It is well known that the prognosis declines with increasing number of metastatic lymph nodes or more precisely, with an increasing lymph node ratio [34, 35]. Larger breast tumors tended to be associated with a greater number of metastatic involved axillary lymph nodes than smaller tumors, indicating that a higher number of involved lymph nodes reflects a longer tumor growth time. In a multivariable logistic regression analysis the molecular subtypes of breast tumors (luminal, luminal/HER2-positive, HER2-positive/ER-negative/progesterone receptor (PgR)-negative, and basal-like) had a predictive effect for nodal involvement $(p=0.000001)$. Using the luminal subtype as reference, the basal subtype has an odds ratio for axillary lymph node involvement of $0.53(95 \% \mathrm{Cl}$ : $0.41-0.69)$ in a model using core biopsy data [36]. A Belgian group reported higher likelihood of being lymph node positive for triplepositive tumors (HER2 positive/ER positive/PgR positive) compared to other subtypes (56.2 vs. $35.7 \%$ ) [37]. Patients older than 70 years were more likely to have positive nodes with increasing age. The effect of age in older women was most pronounced for small tumors. On the contrary, for very large tumors, the risk of lymph node involvement even decreased with increasing age [38]. Other studies reported no increase of lymph node involvement in elderly patients when investigating the 
relationship in PT-strata and adjusting for other prognostic factors. Taken together, axillary lymph node involvement is the result of different factors and lymph node status at all does not reflect the aggressive behavior of the tumor correctly [39]. Tumor aggressiveness especially in patient without axillary lymph node involvement has primarily to do with biological features of the tumor cells from the primary tumor. Based on this, it seems reasonable that poor outcome depends more on the tumor biology than on lymph node involvement [40-44]. Gene expression analyses of the primary tumor indicated that $51 \%$ of lymph node-negative tumors and $49 \%$ of lymph node-positive tumors have a poor prognostic signature [45]. The value of gene expression profiling as a prognostic tool in clinical practice is currently being evaluated in two large, prospective, randomised studies (TAILORx, MINDACT). Lymph node status is a good indicator of tumor stage related to the time point of diagnosis, but it does not reflect the real tumor biology, metastatic behavior as well as sensitivity to systemic treatment. Extensive characterization of the primary tumor will be available by gene signatures in future [44-46]. Nevertheless, nodal status is still an established parameter for treatment decisions in current guidelines. According to the NCCN guidelines the indication for post-mastectomy radiotherapy in all patients or for adjuvant chemotherapy in ER-positive/HER2-negative disease is linked to the number of involved lymph nodes [6].

This adherence to treatment recommendations on the basis of axillary nodal status was also observed in own previous work. We have shown that the knowledge of pathologic nodal status influences the indications for postoperative chemotherapy and post-mastectomy radiotherapy [47]. Re-discussion of postoperative tumor board records without information regarding axillary lymph node status resulted in adjuvant treatment recommendations different from the current guidelines in one third of all cases (72 of 207 patients), especially in carcinomas with present lymphangiosis. 
However, this finding is the result of guidelines which are mostly based on elderly studies with nodal status as an in- or exclusion criterion. More recent studies have confirmed the effectiveness of chemotherapy and trastuzumab even in high risk, node-negative patients $[48,49]$.

Engel et al. reported 15 reasons to stop axillary surgery entirely [50]. This paper was hypothesis generating in 2006 without changing current surgical practice. The author's discussion is based on the hypothesis that locoregional and distant metastases develop over time from disseminated tumor cells that originate from the primary and not from the lymph nodes. The current pros and contras for axillary lymph node status and associated treatment decisions are summarized in table 3 using some arguments published by Engel et al..

\section{Definition of patient subgroups without any axillary surgery}

SLNB is a minimal invasive procedure with the same oncologic safety as ALND and low (but not zero) morbidity [51-53]. Therefore, SLNB is suggested to be an optimal approach to reduce the morbidity by the assessment of axillary status in clinically node-negative breast cancer. But the indication for SLNB in all clinically nodenegative patients is questionable because at least $70 \%$ of these patients are pathologically tumor-free in the axillary nodes. Two randomized trials investigated the use of ALND versus no axillary surgery in elderly patients [54, 55]. A third trial randomized patients without any axillary surgery to no axillary treatment versus axillary radiotherapy (ART) [56]. The results of all three studies showed a very low rate of axillary recurrences, even in the arms without axillary surgery, and comparable disease-free and overall survival (Tab. 4).

In an observational study with 671 consecutive patients, aged $\geq 70$ years, and a clinically tumor-free axilla, 172 received and 499 did not receive axillary dissection. 
After a median follow-up of 15 years, there was no significant difference in breast cancer mortality between the axillary and no axillary clearance groups. Ipsilateral axillary recurrence rate was zero in the axillary dissection group and relatively low in the no axillary dissection group: $5.8 \%$ overall and $3.7 \%$ for pT1 patients [57]. These axillary recurrence rates in the non-operated group were much lower than the rate of pathological nodal involvement in the axillary dissection group $(33.7 \% \mathrm{pN}+$ overall and $29 \% \mathrm{pN}+$ for pT1 patients). The authors concluded, that due to a very low cumulative incidence of axillary recurrence in elderly patients with BCS both, SLNB and ALND can be avoided. Axillary dissection should be restricted to the small number of patients who will later develop apparent axillary disease.

Axillary recurrence is rare, although four-times more common in younger women (<40 years) than in older patients (50-60 years) [58]. Current NCCN guidelines consider the performance of ALND as optional in patients who have particularly favorable tumors, in patients for whom the selection of adjuvant systemic therapy is unlikely to be affected, for the elderly, or those with severe comorbid conditions [6]. There is no clear statement in the NCCN guidelines in which patients the SLNB can be avoided.

ART has been used instead of or in addition to axillary sampling or ALND. In 2004, Louis-Sylvestre et al. published results of a prospective randomized trial comparing lumpectomy plus ART versus lumpectomy plus ALND ( $n=658$; median follow-up 180 months; $21 \%$ node-positive in the ALND group) [59]. Overall survival rates were identical in both groups, recurrences in the axillary nodes were less frequent in the ALND group ( $1 \%$ versus $3 \%, p=0.04)$. As an alternative to completion ALND for SLNB positive patients, ART has been suggested [60]. This concept is undergoing prospective evaluation by the EORTC trial, "After Mapping of the Axilla: Radiotherapy versus Surgery?" (AMAROS) [61]. The trial is full recruited, but definitive data will not 
be available for years. ART in the setting of no prior axillary surgery has generally been associated with less morbidity than that seen with ALND. The incidence of morbidity after SLNB combined with ART has not been well characterized [62].

\section{In situ left metastatic involved axillary lymph nodes and prognosis}

\section{Macrometastases}

SLNB trial arms with immediate conventional ALND showed false-negative rates up to $9.8 \%$ regarding accuracy of SLNB $[2,63]$. Even after ALND of level I and II, up to $30 \%$ of positive lymph nodes remain in the axilla, $15 \%$ of these present as 'skip metastases' $[64,65]$. Rudenstam et al. reported nodal involvement in $28 \%$ of the patients who had axillary dissection [54]. Isolated lymph node recurrences are rare $(<2 \%)$ in patients with BCS and lymph node-positive disease $[58,66,67]$.

The presentation of the prospective, multicentric ACOSOG Z0011 trial at the ASCO Congress 2010 was a landmark for the discussion about surgical options in pN+ patients after SLNB. According to the protocol, nearly 900 patients with clinically T1-2 cN0 cM0 breast cancer and BCS with metastatic involved sentinel nodes (routine hematoxylin and eosin [H\&E] detected) were randomized to no further axillary dissection or completion ALND [68]. Targeted enrollment was 1,900 women, but the trial closed earlier due to lower than expected accrual and event rates. Both arms were comparable with respect to pathological tumor size, grading, histological tumor type, hormone receptor status and systemic treatment. After a median follow up of 6.3 years there were no significant differences between SLNB alone and SLNB plus ALND arms concerning 5-year local recurrence rate (1.6\% versus $3.1 \%$ ), 5-year disease-free survival (83.9\% versus $82.2 \%)$, or 5 -year overall survival $(92.5 \%$ versus $91.8 \%$ ). The local axillary recurrence rate was $0.9 \%$ for SLNB alone and $0.5 \%$ for SLNB+ALND [68, 69]. Because all patients were treated with opposing and 
tangential field irradiation, a local effect on the axilla could not be excluded completely, however it seems very unlikely in this dimension $[58,66]$.

According to these findings the German AGO Breast Group has adapted the current guidelines in March 2011. The completion ALND is not longer recommended (only "+/-" grade of recommendation) in patients with positive sentinel nodes and: cT1/2, $\mathrm{cN}$, less than three sentinel nodes involved, BCS plus tangential breast irradiation, and no alternative ART [5]. The ACOSOG Z0011 data are supported by a retrospective SEER database analysis (1998-2004) including 26,986 patients with positive sentinel nodes [70]. Among those, 4,425 (16.4\%) underwent SLNB alone, and 22,561 (83.6\%) underwent SLNB with completion ALND. Contrary to the Z0011 study, the SEER analysis was not restricted to BCS $(21.2 \%$ with total mastectomy in the SLNB alone arm). At a median follow-up of 50 months, there were no statistically significant differences in overall survival between patients with SLNB alone versus complete ALND.

Of 97,314 patients from the US National Cancer Database who underwent SLNB and who had nodal metastases, $20.8 \%$ underwent SLNB alone, and $79.2 \%$ underwent SLNB with complete ALND [71]. In patients with macroscopic nodal metastases and a median follow-up of 63 months, there was a non-significant trend towards better outcomes for complete ALND compared to SLNB alone: axillary recurrence HR=0.58 (95\% Cl: 0.32-1.06) and overall survival $\mathrm{HR}=0.89$ (95\% Cl: $0.76-1.04)$. A randomized controlled trial with 30 years follow-up indicated that clearing the internal mammary or axillary lymph nodes has no impact on long-term survival [72]. Moreover, tumor location affects the frequency of lymph node metastases but not the survival. Janni et al. showed that $25.8 \%$ of patients with a tumor in the medial quadrant of the breast have axillary lymph node metastases compared with $35.5 \%$ of patients with a lateral localized breast tumor [73]. Despite the $10 \%$ difference, survival time was similar for 
both tumor locations. There is no additional survival advantage in clearing level III of the axilla compared with clearing restricted to levels I and II [74].

The Memorial Sloan-Kettering Cancer Center (MSKCC) developed nomograms to predict the likelihood of a positive sentinel node or finding additional positive nonsentinel nodes in patients with involved SLNs $[75,76]$. The nomograms are a statistical approach for calculation metastatic axillary risk by combining different histopathologic factors (plus age, which is incorporated in the sentinel nomogram) and are available online (www.mskcc.org/mskcc/html/15938.cfm). Although the first published MKSCC nomogram for patients with positive SLN has been validated by numerous centers, clinicians were unlikely to change their surgical plan based on nomogram results [77]. Additionally, this model seems not reliable predictive for positive non-SLN in cases with micrometastatic positive SLN [78].

\section{Micrometastases}

The SLN is the most likely site of regional metastasis, and gives pathologists the opportunity to concentrate detection techniques on one or a few lymph nodes. The use of step sectioning and immunohistochemistry for SLN analysis results in a higher detection rate of micrometastases (International Union Against Cancer classification: pN1mi, $>0.2 \mathrm{~mm}$ to $\leq 2.0 \mathrm{~mm}$ ) and isolated tumor cells (pNo(i+), $\leq 0.2 \mathrm{~mm})$ [79-81]. Pathologists should follow published recommendations for the management of SLN $[2,82,83]$.

Breast cancer micrometastases have lower tumor proliferation rates and angiogenesis than breast cancer macrometastases [84]. These characteristics may explain a discrimination of micro- and macrometastases. The distinction between pN1mi and pNO(i+) depends on $0.1 \mathrm{~mm}$. Why should $0.1 \mathrm{~mm}$ in tumor cluster size determine different prognosis? Any tumor spread to axillary lymph nodes indicates 
that the tumor cells are able to metastasize. Therefore the meaningfulness of distinction between pN1mi and pNO(i+) and also pN1a must be challenged [85].

Tan et al. reported a significant decreased disease-free and overall survival for pN0(i+) patients $(\mathrm{HR}=1.7[95 \% \mathrm{Cl}: 1.0-2.9])$ compared to $\mathrm{pNO}(\mathrm{i}-)$ in a retrospective analysis with 17.6 years follow-up [86]. Many studies confirmed that the occurrence of $\mathrm{pN} 1 \mathrm{mi}$ and $\mathrm{pNO}(\mathrm{i}+)$ depends on the tumor biology and the location of micrometastases (sinusal versus parenchymal) [66, 87-94]. However, the clinical relevance and therapeutic implications of $\mathrm{pN} 1 \mathrm{mi}$ and $\mathrm{pNO}(\mathrm{i}+)$ in the $\mathrm{SLN}$ remain a matter of debate.

A recent meta-analysis including 297,533 patients from 58 studies published between 1977 and August 2008 divided patients into three categories according to the method of pathological assessment of the lymph nodes: cohort studies with single-section examination ( $n=285,638$ patients), occult metastases studies with retrospective examination of negative lymph nodes by step sectioning and/or immunohistochemistry ( $n=7,740$ patients), and SLNB studies with intensified work-up of the sentinel but not of the non-SLN ( $n=4,155$ patients) [95]. In the cohort studies, axillary lymph node metastases of $2 \mathrm{~mm}$ or less in diameter were associated with poorer overall survival $(\mathrm{HR}=1.44,95 \% \mathrm{Cl}: 1.29-1.62)$, occult metastases were associated with poorer 5-year disease-free survival ( $R R=1.55,95 \% \mathrm{Cl}: 1.32-1.82)$ and overall survival $(R R=1.45,95 \% \mathrm{Cl}: 1.11-1.88)$, although these endpoints were not consistently assessed in multivariable analyses. SLNB studies are limited by small patient numbers, SLNB alone or complete ALND in pN1mi and/or pNO(i+), different systemic treatments, and short follow-up.

As shown in table 5 , nine of 12 studies reporting survival outcome, demonstrate no associations between occult metastases and overall survival. The MIRROR study (Micrometastases and Isolated tumor cells: Relevant and Robust or Rubbish) has 
found $\mathrm{pNO}(\mathrm{i}+)$ and also $\mathrm{pN} 1 \mathrm{mi}$ to be indicators of poor prognosis compared to $\mathrm{pNO}$ [89]. The MIRROR-trial is also a retrospective cohort study including only patients with favorable tumor characteristics for whom adjuvant systemic treatment was not indicated according to the Dutch treatment guidelines. ITCs or micrometastases in regional lymph nodes were associated with a reduced 5-year rate of disease-free survival among patients who did not receive adjuvant therapy (HR $1.5[95 \% \mathrm{Cl}: 1.15-$ 1.94] for ITC and $\mathrm{HR} 1.56$ [95\% Cl: 1.15-2.12] for pN1mi). In patients with ITC or micrometastases who received adjuvant therapy, disease-free survival was significantly improved as compared with the node-positive, no-adjuvant-therapy cohort [89].

A recent study showed that the actual rate of positive non-SLNs for patients with SLN micrometastases or ITCs who underwent completion ALND was significantly less than that predicted by the MSKCC nomogram [104]. The rate of axillary recurrence for included 116 patients with stage I to III breast cancer was negligible, regardless of the extent of axillary staging. The NSABP trial B-32 investigated the clinical significance of occult metastatic disease in selected sentinel nodes - primary pathologically negative [96]. Occult metastases were detected in $15.9 \%$ of 3,887 patients: $11.1 \%$ with ITC clusters, $4.4 \%$ with micrometastases, and $0.4 \%$ with macrometastases. Occult metastases were an independent prognostic variable; however, the magnitude of the difference in overall survival at 5 years was small (94.6\% with and $95.8 \%$ without detectable metastases). The authors conclude, that identification of occult metastases does not appear to be clinically useful for patients with newly diagnosed disease in whom systemic therapy can be recommended on the basis of the characteristics of the primary tumor.

\section{Do lymph node metastases metastasize?}


The key question, whether regional lymphatic metastases can further metastasize to distant organs like the liver, lung or bone or not, is currently unanswered [105]. The process of metastatic spread is highly complex involving more than 250 genes, multiple mutations and cell evolutions, and is organotropic [105-109]. Metastatic spread of tumor cells to regional lymph nodes via lymphatic vessels is not a passive, but a highly complex active process with specific interaction of tumor cells and lymphatic tissue [110]. If radio-labeled tumor cells are injected into the afferent nodal lymphatic vessel, they rapidly appear in the efferent lymphatic vessel and the thoracic duct, showing, that the lymph node is not only a simple cell-filter [111]. Metastasis to lymph nodes is positively correlated to enhanced peritumoral lymphangiogenesis, which results from expression of vascular endothelial growth factor (VEGF)-C. VEGF-C binds to the VEGF receptor (VEGFR)-3 on lymphatic endothelial cells and induces lymphangiogenesis $[112,113]$. High levels of VEGF-C and VEGFR-3 are not only associated with an increase of lymph node metastasis but also with poor overall survival without affecting the growth of the primary tumor. VEGF-C-induced lymphangiogenesis in SLN promotes tumor metastasis spread to distant sites $[114,115]$. These results implicate the possibility of further metastasis to distant organs from the lymph nodes via the thoracic duct. According to the soil and seed hypothesis of Paget the fate of a circulating tumor cell is also strongly controlled by the organ of metastasis resting upon complex cell-cell and cell-matrix interactions. Key players in lymph node metastasis are the chemokines CXCL12 and CCL21, produced by the lymphatic tissue. They are attractants for tumor cells which express the chemokine receptors CXCR4 or CCR7 [110]. High expression of these receptors is associated with higher incidence of lymph node metastasis in breast cancer patients [116, 117]. A significant number of patients show discordant quantitative expression of molecular markers between primary and nodal disease indicating a 
organotropy [118]. This concept of organ site specificity corroborates the hypothesis, that lymph node metastases do not further spread or if they do only into lymph nodes down stream the metastatic one. The lack of lung metastases in patients with a palliative peritoneo-venous shunt in cases of malignant ascites impressively emphasizes this hypothesis [119]. But as a result of genetic instability, metastases that are initially of clonal origin, continuously acquire a genetic heterogeneity which could result in metastatic transformation of some cells, that permit a further spread to distant sites [119]. However, animal studies with inhibition of lymph node metastases are inconsistent and do not clearly confirm the hypothesis of a "metachronous seeding" [120].

It is widely accepted that also small tumors could early spread to distant sites. Micrometastases have occurred in $20-40 \%$ of carcinomas in the absence of other detectable signs of spread $[88,121]$. Micrometastases as well as the number of circulating tumor cells are associated with the incidence of distant metastases as well as with the overall survival of breast cancer patients [122-124]. For patient's prognosis, these parameters of tumor spread could be more relevant than the likelihood of a metastasis from lymph nodes $[125,126]$. Therefore we need effective treatment strategies for these probably stem cell like tumor cells [127-130]. In conclusion, there is increasing doubt, that lymph node metastasis are able to metastasize. The life threatening effect of lymph node metastases is overestimated.

\section{Conclusion:}

Increasing data suggest that surgical management of the axilla by SLNB or ALND has no influence on recurrence-free and overall survival in all breast cancer patients. However, sample size and length of follow-up are substantially different between cited studies, so that definitive conclusions can not be made. Case reports suggest 
that patients with axillary metastases alone after SLNB, who had undergone delayed ALND, have no prognostic disadvantage. With the exception of the ACOSOG Z0011 trial, there are no data from large randomized clinical trials that support or refuse this hypothesis. There is high evidence to avoid any axillary surgery in elderly patients with favorable tumor biology (older than 60 years, pT1, G1-2, hormone sensitivity, no clinically and sonographically involved axillary lymph nodes).

It might be academically interesting to discuss about micrometastases and immunohistochemically detected tumor cells or tumor cell clusters in the SLN. On the other hand, we urgently need to initiate randomized clinical trials to avoid any axillary surgery in most patients with breast cancer and no clinically considerable enlarged axillary lymph nodes. As the ACOSOG Z0011 trial has shown, patients can be motivated to participate in randomized trials with restricted axillary surgery. Nonetheless, a rational and evidence-based approach to the management of clinically and sonographically NO patients with planned BCS and limited tumor size is needed now. Risk estimates using the MSKCC nomogram to predict likelihood of SLN metastases may be helpful for the decision regarding pro or contra axillary surgery outside from clinical trials. In patients with BCS without any axillary surgery an additional regional treatment effect can be expected by postoperative external beam radiotherapy because traditionally defined tangential breast fields include the majority (60\%-90\%) of level I lymph nodes [62].

Surgeons, radiologists, and pathologists should work together to avoid unnecessary axillary surgery. There is an urgent need for simple but reproducible and validated sonographic criteria to categorize patients as cNO/iNO (imaging N0) correctly in the preoperative setting. Future studies should also include patients with total mastectomy and favorable tumor biology to prove the value of axillary clearance for local recurrence and survival rates. It took some decades to replace the radical 
Halsted theory by new paradigms including BCS. Similarly, the performance of axillary surgery has to be questioned. 
References

1. Schwartz GF, Guiliano AE, Veronesi U: Proceeding of the consensus conference of the role of sentinel lymph node biopsy in carcinoma or the breast April 1922, 2001, Philadelphia, PA, USA. Breast J 8:124-138, 2002

2. Lyman GH, Giuliano AE, Somerfield MR et al: American Society of Clinical Oncology guideline recommendations for sentinel lymph node biopsy in earlystage breast cancer. J Clin Oncol 23:7703-7720, 2005

3. Krag DN, Anderson SJ, Julian TB et al: Sentinel-lymph-node resection compared with conventional axillary-lymph-node dissection in clinically node-negative patients with breast cancer: overall survival findings from the NSABP B-32 randomised phase 3 trial. Lancet Oncol 11:927-933, 2010

4. Crane-Okada R, Wascher RA, Elashoff $D$ et al: Long-term morbidity of sentinel node biopsy versus complete axillary dissection for unilateral breast cancer. Ann Surg Oncol 15:1996-2005, 2008

5. AGO: Diagnostic and treatment of early and metastatic breast cancer. http://www.ago-online.org. 2011

6. NCCN (National Comprehensive Cancer Network). NCCN Practice Guidelines in Oncology: Breast Cancer. Version 02.2011. http://www.nccn.org. 2011.

7. Cochrane Collaboration. http://www.cochrane.org. 2010.

8. Lanng C, Hoffmann J, Galatius $\mathrm{H}$ et al: Assessment of clinical palpation of the axilla as a criterion for performing the sentinel node procedure in breast cancer. Eur J Surg Oncol 33:281-284, 2007 
9. Specht MC, Fey JV, Borgen PI et al: Is the clinically positive axilla in breast cancer really a contraindication to sentinel lymph node biopsy? J Am Coll Surg $200: 10-14,2005$

10. Mathijssen IM, Strijdhorst H, Kiestra SK et al: Added value of ultrasound in screening the clinically negative axilla in breast cancer. J Surg Oncol 94:364367,2006

11. Zgajnar J, Hocevar M, Podkrajsek $M$ et al: Patients with preoperatively ultrasonically uninvolved axillary lymph nodes: a distinct subgroup of early breast cancer patients. Breast Cancer Res Treat 97:293-299, 2006

12. Boughey JC, Moriarty JP, Degnim AC et al: Cost modeling of preoperative axillary ultrasound and fine-needle aspiration to guide surgery for invasive breast cancer. Ann Surg Oncol 17:953-958, 2010

13. Park SH, Kim MJ, Park BW et al: Impact of preoperative ultrasonography and fine-needle aspiration of axillary lymph nodes on surgical management of primary breast cancer. Ann Surg Oncol 18:738-744, 2011

14. Baruah BP, Goyal A, Young P et al: Axillary node staging by ultrasonography and fine-needle aspiration cytology in patients with breast cancer. $\mathrm{Br} \mathrm{J}$ Surg $97: 680-683,2010$

15. Alvarez S, Anorbe E, Alcorta P et al: Role of sonography in the diagnosis of axillary lymph node metastases in breast cancer: a systematic review. AJR Am J Roentgenol 186:1342-1348, 2006

16. Garcia Fernandez A, Fraile M, Gimenez $N$ et al: Use of axillary ultrasound, ultrasound-fine needle aspiration biopsy and magnetic resonance imaging in 
the preoperative triage of breast cancer patients considered for sentinel node biopsy. Ultrasound Med Biol 37:16-22, 2011

17. Mainiero MB, Cinelli CM, Koelliker SL et al: Axillary ultrasound and fine-needle aspiration in the preoperative evaluation of the breast cancer patient: an algorithm based on tumor size and lymph node appearance. AJR Am J Roentgenol 195:1261-1267, 2010

18. Cho N, Moon WK, Han W et al: Preoperative sonographic classification of axillary lymph nodes in patients with breast cancer: node-to-node correlation with surgical histology and sentinel node biopsy results. AJR Am J Roentgenol 193:1731-1737, 2009

19. Steppan I, Reimer D, Muller-Holzner E et al: Breast cancer in women: evaluation of benign and malignant axillary lymph nodes with contrast-enhanced ultrasound. Ultraschall Med 31:63-67, 2010

20. Sloka JS, Hollett PD, Mathews M: A quantitative review of the use of FDG-PET in the axillary staging of breast cancer. Med Sci Monit 13:RA37-46, 2007

21. Peare R, Staff RT, Heys SD: The use of FDG-PET in assessing axillary lymph node status in breast cancer: a systematic review and meta-analysis of the literature. Breast Cancer Res Treat 123:281-290, 2010

22. Straver ME, Aukema TS, Olmos RA et al: Feasibility of FDG PET/CT to monitor the response of axillary lymph node metastases to neoadjuvant chemotherapy in breast cancer patients. Eur J Nucl Med Mol Imaging 37:1069-1076, 2010

23. Ahn JH, Son EJ, Kim JA et al: The role of ultrasonography and FDG-PET in axillary lymph node staging of breast cancer. Acta Radiol 51:859-865, 2010 
24. Harada T, Tanigawa N, Matsuki M et al: Evaluation of lymph node metastases of breast cancer using ultrasmall superparamagnetic iron oxide-enhanced magnetic resonance imaging. Eur J Radiol 63:401-407, 2007

25. Stadnik TW, Everaert H, Makkat $S$ et al: Breast imaging. Preoperative breast cancer staging: comparison of USPIO-enhanced MR imaging and 18Ffluorodeoxyglucose (FDG) positron emission tomography (PET) imaging for axillary lymph node staging--initial findings. Eur Radiol 16:2153-2160, 2006

26. Murray AD, Staff RT, Redpath TW et al: Dynamic contrast enhanced MRI of the axilla in women with breast cancer: comparison with pathology of excised nodes. Br J Radiol 75:220-228, 2002

27. Michel SC, Keller TM, Frohlich JM et al: Preoperative breast cancer staging: MR imaging of the axilla with ultrasmall superparamagnetic iron oxide enhancement. Radiology 225:527-536, 2002

28. Memarsadeghi M, Riedl CC, Kaneider A et al: Axillary lymph node metastases in patients with breast carcinomas: assessment with nonenhanced versus uspioenhanced MR imaging. Radiology 241:367-377, 2006

29. Suzuma T, Sakurai T, Yoshimura G et al: MR-axillography oriented surgical sampling for assessment of nodal status in the selection of patients with breast cancer for axillary lymph nodes dissection. Breast Cancer 9:69-74, 2002

30. Stets $\mathrm{C}$, Brandt $\mathrm{S}$, Wallis $\mathrm{F}$ et al: Axillary lymph node metastases: a statistical analysis of various parameters in MRI with USPIO. J Magn Reson Imaging 16:60-68, 2002 
31. Kitagawa K, Sakuma H, Ishida N et al: Contrast-enhanced high-resolution MRI of invasive breast cancer: correlation with histopathologic subtypes. AJR Am J Roentgenol 183:1805-1809, 2004

32. Bathen TF, Jensen LR, Sitter B et al: MR-determined metabolic phenotype of breast cancer in prediction of lymphatic spread, grade, and hormone status. Breast Cancer Res Treat 104:181-189, 2007

33. Gelmon KA: The ongoing debate about nodes. Clin Breast Cancer 10:265-266, 2010

34. Tai P, Yu E, Joseph K: Prognostic significance of number of positive nodes: a long-term study of one to two nodes versus three nodes in breast cancer patients. Int J Radiat Oncol Biol Phys 77:180-187, 2010

35. Hatoum HA, Jamali FR, El Saghir NS et al: Ratio between positive lymph nodes and total excised axillary lymph nodes as an independent prognostic factor for overall survival in patients with nonmetastatic lymph node-positive breast cancer. Ann Surg Oncol 16:3388-3395, 2009

36. Crabb SJ, Cheang MC, Leung $S$ et al: Basal breast cancer molecular subtype predicts for lower incidence of axillary lymph node metastases in primary breast cancer. Clin Breast Cancer 8:249-256, 2008

37. Van Calster B, Vanden Bempt I, Drijkoningen M et al: Axillary lymph node status of operable breast cancers by combined steroid receptor and HER-2 status: triple positive tumours are more likely lymph node positive. Breast Cancer Res Treat 113:181-187, 2009 
38. Wildiers H, Van Calster B, van de Poll-Franse LV et al: Relationship between age and axillary lymph node involvement in women with breast cancer. J Clin Oncol 27:2931-2937, 2009

39. Botteri E, Bagnardi V, Goldhirsch A et al: Axillary lymph node involvement in women with breast cancer: does it depend on age? Clin Breast Cancer 10:318-321, 2010

40. Kennecke $H$, Yerushalmi R, Woods R et al: Metastatic behavior of breast cancer subtypes. J Clin Oncol 28:3271-3277, 2010

41. Voduc KD, Cheang MC, Tyldesley S et al: Breast cancer subtypes and the risk of local and regional relapse. J Clin Oncol 28:1684-1691, 2010

42. Foulkes WD, Grainge MJ, Rakha EA et al: Tumor size is an unreliable predictor of prognosis in basal-like breast cancers and does not correlate closely with lymph node status. Breast Cancer Res Treat 117:199-204, 2009

43. Blows FM, Driver KE, Schmidt MK et al: Subtyping of breast cancer by immunohistochemistry to investigate a relationship between subtype and short and long term survival: a collaborative analysis of data for 10,159 cases from 12 studies. PLoS Med 7:e1000279, 2010

44. Huber KE, Carey LA, Wazer DE: Breast cancer molecular subtypes in patients with locally advanced disease: impact on prognosis, patterns of recurrence, and response to therapy. Semin Radiat Oncol 19:204-210, 2009

45. van de Vijver MJ, He YD, van't Veer LJ et al: A gene-expression signature as a predictor of survival in breast cancer. N Engl J Med 347:1999-2009, 2002 
46. Sorlie T, Perou CM, Tibshirani R et al: Gene expression patterns of breast carcinomas distinguish tumor subclasses with clinical implications. Proc Natl Acad Sci U S A 98:10869-10874, 2001

47. Reimer T, Fietkau R, Markmann S et al: How important is the axillary nodal status for adjuvant treatment decisions at a breast cancer multidisciplinary tumor board? A survival analysis. Ann Surg Oncol 15:472-477, 2008

48. Martin M, Segui MA, Anton A et al: Adjuvant docetaxel for high-risk, nodenegative breast cancer. N Engl J Med 363:2200-2210, 2010

49. Untch M, Gelber RD, Jackisch $C$ et al: Estimating the magnitude of trastuzumab effects within patient subgroups in the HERA trial. Ann Oncol 19:1090-1096, 2008

50. Engel J, Lebeau A, Sauer $\mathrm{H}$ et al: Are we wasting our time with the sentinel technique? Fifteen reasons to stop axilla dissection. Breast 15:452-455, 2006

51. Moon HG, Han W, Noh DY: Comparable survival between pNO breast cancer patients undergoing sentinel node biopsy and extensive axillary dissection: a report from the Korean Breast Cancer Society. J Clin Oncol 28:1692-1699, 2010

52. Kell MR, Burke JP, Barry M et al: Outcome of axillary staging in early breast cancer: a meta-analysis. Breast Cancer Res Treat 120:441-447, 2010

53. Land SR, Kopec JA, Julian TB et al: Patient-reported outcomes in sentinel nodenegative adjuvant breast cancer patients receiving sentinel-node biopsy or axillary dissection: National Surgical Adjuvant Breast and Bowel Project phase III protocol B-32. J Clin Oncol 28:3929-3936, 2010 
54. Rudenstam CM, Zahrieh D, Forbes JF et al: Randomized trial comparing axillary clearance versus no axillary clearance in older patients with breast cancer: first results of International Breast Cancer Study Group Trial 10-93. J Clin Oncol 24:337-344, 2006

55. Martelli G, Boracchi $\mathrm{P}$, De Palo $\mathrm{M}$ et al: A randomized trial comparing axillary dissection to no axillary dissection in older patients with T1N0 breast cancer: results after 5 years of follow-up. Ann Surg 242:1-6, 2005

56. Veronesi $U$, Orecchia R, Zurrida $S$ et al: Avoiding axillary dissection in breast cancer surgery: a randomized trial to assess the role of axillary radiotherapy. Ann Oncol 16:383-388, 2005

57. Martelli G, Miceli R, Daidone MG et al: Axillary Dissection Versus No Axillary Dissection in Elderly Patients with Breast Cancer and No Palpable Axillary Nodes: Results After 15 Years of Follow-Up. Ann Surg Oncol 18:125-133, 2011

58. Fredriksson I, Liljegren G, Arnesson LG et al: Consequences of axillary recurrence after conservative breast surgery. Br J Surg 89:902-908, 2002

59. Louis-Sylvestre C, Clough K, Asselain B et al: Axillary treatment in conservative management of operable breast cancer: dissection or radiotherapy? Results of a randomized study with 15 years of follow-up. J Clin Oncol 22:97-101, 2004

60. Bourez R, Rutgers E, van de Velde C: Will we need lymph node dissection at all in the future? Clin Breast Cancer 3:315-322, 2002 
61. Straver ME, Meijnen P, van Tienhoven G et al: Sentinel node identification rate and nodal involvement in the EORTC 10981-22023 AMAROS trial. Ann Surg Oncol 17:1854-1861, 2010

62. Evans SB, Gass J, Wazer DE: Management of the axilla after the finding of a positive sentinel lymph node: a proposal for an evidence-based risk-adapted algorithm. Am J Clin Oncol 31:293-299, 2008

63. Krag DN, Anderson SJ, Julian TB et al: Technical outcomes of sentinel-lymphnode resection and conventional axillary-lymph-node dissection in patients with clinically node-negative breast cancer: results from the NSABP B-32 randomised phase III trial. Lancet Oncol 8:881-888, 2007

64. Canavese G, Catturich A, Vecchio C et al: Prognostic role of lymph-node level involvement in patients undergoing axillary dissection for breast cancer. Eur $\mathrm{J}$ Surg Oncol 24:104-109, 1998

65. Erb KM, Julian TB: Completion of axillary dissection for a positive sentinel node: necessary or not? Curr Oncol Rep 11:15-20, 2009

66. Wo JY, Taghian AG, Nguyen PL et al: The association between biological subtype and isolated regional nodal failure after breast-conserving therapy. Int J Radiat Oncol Biol Phys 77:188-196, 2010

67. Wapnir IL, Anderson SJ, Mamounas EP et al: Prognosis after ipsilateral breast tumor recurrence and locoregional recurrences in five National Surgical Adjuvant Breast and Bowel Project node-positive adjuvant breast cancer trials. J Clin Oncol 24:2028-2037, 2006 
68. Giuliano AE, McCall L, Beitsch $P$ et al: Locoregional recurrence after sentinel lymph node dissection with or without axillary dissection in patients with sentinel lymph node metastases: the American College of Surgeons Oncology Group Z0011 randomized trial. Ann Surg 252:426-432, 2010

69. Giuliano AE, Hunt KK, Ballman KV et al: Axillary dissection vs no axillary dissection in women with invasive breast cancer and sentinel node metastasis. JAMA 305:569-575, 2011

70. Yi M, Giordano SH, Meric-Bernstam F et al: Trends in and outcomes from sentinel lymph node biopsy (SLNB) alone vs. SLNB with axillary lymph node dissection for node-positive breast cancer patients: experience from the SEER database. Ann Surg Oncol 17:S343-S351, 2010

71. Bilimoria KY, Bentrem DJ, Hansen NM et al: Comparison of sentinel lymph node biopsy alone and completion axillary lymph node dissection for node-positive breast cancer. J Clin Oncol 27:2946-2953, 2009

72. Veronesi $U$, Marubini $E$, Mariani $L$ et al: The dissection of internal mammary nodes does not improve the survival of breast cancer patients. 30-year results of a randomised trial. Eur J Cancer 35:1320-1325, 1999

73. Janni W, Rack B, Sommer $\mathrm{H}$ et al: Intra-mammary tumor location does not influence prognosis but influences the prevalence of axillary lymph-node metastases. J Cancer Res Clin Oncol 129:503-510, 2003

74. Sinha PS, Thrush S, Bendall S et al: Does radical surgery to the axilla give a survival advantage in more severe breast cancer? Eur J Cancer 38:14741477,2002 
75. Van Zee KJ, Manasseh DM, Bevilacqua JL et al: A nomogram for predicting the likelihood in breast cancer patients with a positive sentinel node biopsy. Ann Surg Oncol 10:1140-1151, 2003

76. Bevilacqua JL, Kattan MW, Fey JV et al: Doctor, what are my chances of having a positive sentinel node? A validated nomogram for risk estimation. J Clin Oncol 25:3670-3679, 2007

77. Specht MC, Kattan MW, Fey $\mathrm{J}$ et al: Predicting nonsentinel node status after positive sentinel lymph node biopsy for breast cancer: clinicians versus nomogram. Ann Surg Oncol 12:654-659, 2005

78. Alran S, De Rycke $\mathrm{Y}$, Fourchotte $\mathrm{V}$ et al: Validation and limitations of use of a breast cancer nomogram predicting the likelihood of non-sentinel node involvement after positive sentinel node biopsy. Ann Surg Oncol 14:21952201,2007

79. Cserni G, Gregori D, Merletti F et al: Meta-analysis of non-sentinel node metastases associated with micrometastatic sentinel nodes in breast cancer. Br J Surg 91:1245-1252, 2004

80. Langer I, Guller U, Viehl CT et al: Axillary lymph node dissection for sentinel lymph node micrometastases may be safely omitted in early-stage breast cancer patients: long-term outcomes of a prospective study. Ann Surg Oncol 16:3366-3374, 2009

81. Sahin AA, Guray M, Hunt KK: Identification and biologic significance of micrometastases in axillary lymph nodes in patients with invasive breast cancer. Arch Pathol Lab Med 133:869-878, 2009 
82. Cserni G, Amendoeira I, Apostolikas N et al: Pathological work-up of sentinel lymph nodes in breast cancer. Review of current data to be considered for the formulation of guidelines. Eur J Cancer 39:1654-1667, 2003

83. Turner RR, Weaver DL, Cserni G et al: Nodal stage classification for breast carcinoma: improving interobserver reproducibility through standardized histologic criteria and image-based training. J Clin Oncol 26:258-263, 2008

84. Klauber-DeMore N, Van Zee KJ, Linkov I et al: Biological behavior of human breast cancer micrometastases. Clin Cancer Res 7:2434-2439, 2001

85. de Mascarel I, MacGrogan G, Debled M et al: Distinction between isolated tumor cells and micrometastases in breast cancer: is it reliable and useful? Cancer $112: 1672-1678,2008$

86. Tan LK, Giri D, Hummer AJ et al: Occult axillary node metastases in breast cancer are prognostically significant: results in 368 node-negative patients with 20-year follow-up. J Clin Oncol 26:1803-1809, 2008

87. Yegiyants S, Romero LM, Haigh PI et al: Completion axillary lymph node dissection not required for regional control in patients with breast cancer who have micrometastases in a sentinel node. Arch Surg 145:564-569, 2010

88. Gerber B, Krause A, Muller H et al: Simultaneous immunohistochemical detection of tumor cells in lymph nodes and bone marrow aspirates in breast cancer and its correlation with other prognostic factors. J Clin Oncol 19:960-971, 2001

89. de Boer M, van Deurzen $\mathrm{CH}$, van Dijck JA et al: Micrometastases or isolated tumor cells and the outcome of breast cancer. N Engl J Med 361:653-663, 2009 
90. van Diest PJ, de Boer M, van Deurzen $\mathrm{CH}$ et al: Micrometastases and isolated tumor cells in breast cancer are indeed associated with poorer outcome. J Clin Oncol 28:e140-e142, 2010

91. Hansen NM, Grube B, Ye X et al: Impact of micrometastases in the sentinel node of patients with invasive breast cancer. J Clin Oncol 27:4679-4684, 2009

92. Reed J, Rosman M, Verbanac KM et al: Prognostic implications of isolated tumor cells and micrometastases in sentinel nodes of patients with invasive breast cancer: 10-year analysis of patients enrolled in the prospective East Carolina University/Anne Arundel Medical Center Sentinel Node Multicenter Study. J Am Coll Surg 208:333-340, 2009

93. van der Ploeg I, Nieweg OE, van Rijk MC et al: Axillary recurrence after a tumour-negative sentinel node biopsy in breast cancer patients: A systematic review and meta-analysis of the literature. Eur J Surg Oncol 34:1277-1284, 2008

94. Masci G, Di Tommaso L, Del Prato I et al: Sinusal localization of nodal micrometastases is a prognostic factor in breast cancer. Ann Oncol 21:12281232, 2010

95. de Boer M, van Dijck JA, Bult P et al: Breast cancer prognosis and occult lymph node metastases, isolated tumor cells, and micrometastases. J Natl Cancer Inst 102:410-425, 2010

96. Weaver DL, Ashikaga T, Krag DN et al: Effect of occult metastases on survival in node-negative breast cancer. N Engl J Med 364:412-421, 2011 
97. Maaskant-Braat AJ, van de Poll-Franse LV, Voogd AC et al: Sentinel node micrometastases in breast cancer do not affect prognosis: a population-based study. Breast Cancer Res Treat 2010 Aug 3 [Epub ahead of print]

98. Montagna $\mathrm{E}$, Viale $\mathrm{G}$, Rotmensz $\mathrm{N}$ et al: Minimal axillary lymph node involvement in breast cancer has different prognostic implications according to the staging procedure. Breast Cancer Res Treat 118:385-394, 2009

99. Gobardhan PD, Elias SG, Madsen EV et al: Prognostic value of micrometastases in sentinel lymph nodes of patients with breast carcinoma: a cohort study. Ann Oncol 20:41-48, 2009

100. Cox CE, Kiluk JV, Riker Al et al: Significance of sentinel lymph node micrometastases in human breast cancer. J Am Coll Surg 206:261-268, 2008

101. Nagashima T, Sakakibara M, Nakano $S$ et al: Sentinel node micrometastasis and distant failure in breast cancer patients. Breast Cancer 13:186-191, 2006

102. Imoto S, Ochiai A, Okumura $C$ et al: Impact of isolated tumor cells in sentinel lymph nodes detected by immunohistochemical staining. Eur J Surg Oncol $32: 1175-1179,2006$

103. Fan YG, Tan YY, Wu CT et al: The effect of sentinel node tumor burden on nonsentinel node status and recurrence rates in breast cancer. Ann Surg Oncol 12:705-711, 2005

104. Cyr A, Gillanders WE, Aft RL et al: Micrometastatic disease and isolated tumor cells as a predictor for additional breast cancer axillary metastatic burden. Ann Surg Oncol 17:S303-S311, 2010 
105. Tait CR, Dodwell D, Horgan K: Do metastases metastasize? J Pathol 203:515518,2004

106. Bernards R, Weinberg RA: A progression puzzle. Nature 418:823, 2002

107. Lu X, Yan $\mathrm{CH}$, Yuan M et al: In vivo dynamics and distinct functions of hypoxia in primary tumor growth and organotropic metastasis of breast cancer. Cancer Res 70:3905-3914, 2010

108. Lu X, Kang Y: Organotropism of breast cancer metastasis. J Mammary Gland Biol Neoplasia 12:153-162, 2007

109. Smid M, Wang Y, Zhang Y et al: Subtypes of breast cancer show preferential site of relapse. Cancer Res 68:3108-3114, 2008

110. Ran S, Volk L, Hall $\mathrm{K}$ et al: Lymphangiogenesis and lymphatic metastasis in breast cancer. Pathophysiology 17:229-251, 2010

111. Fisher B, Fisher ER: Transmigration of lymph nodes by tumor cells. Science $152: 1397-1398,1966$

112. Krishnan J, Kirkin V, Steffen A et al: Differential in vivo and in vitro expression of vascular endothelial growth factor (VEGF)-C and VEGF-D in tumors and its relationship to lymphatic metastasis in immunocompetent rats. Cancer Res 63:713-722, 2003

113. Hirakawa S, Brown LF, Kodama S et al: VEGF-C-induced lymphangiogenesis in sentinel lymph nodes promotes tumor metastasis to distant sites. Blood 109:1010-1017, 2007 
114. Mohammed RA, Green A, El Shikh S et al: Prognostic significance of vascular endothelial cell growth factors $-A,-C$ and $-D$ in breast cancer and their relationship with angio- and lymphangiogenesis. Br J Cancer 96:1092-1100, 2007

115. Nakamura $Y$, Yasuoka $H$, Tsujimoto $M$ et al: Lymph vessel density correlates with nodal status, VEGF-C expression, and prognosis in breast cancer. Breast Cancer Res Treat 91:125-132, 2005

116. Yasuoka H, Tsujimoto M, Yoshidome $\mathrm{K}$ et al: Cytoplasmic CXCR4 expression in breast cancer: induction by nitric oxide and correlation with lymph node metastasis and poor prognosis. BMC Cancer 8:340, 2008

117. Cabioglu N, Yazici MS, Arun B et al: CCR7 and CXCR4 as novel biomarkers predicting axillary lymph node metastasis in T1 breast cancer. Clin Cancer Res 11:5686-5693, 2005

118. Aitken SJ, Thomas JS, Langdon SP et al: Quantitative analysis of changes in ER, PR and HER2 expression in primary breast cancer and paired nodal metastases. Ann Oncol 21:1254-1261, 2010

119. Fidler IJ: The pathogenesis of cancer metastasis: the 'seed and soil' hypothesis revisited. Nat Rev Cancer 3:453-458, 2003

120. Wong SY, Hynes RO: Lymphatic or hematogenous dissemination: how does a metastatic tumor cell decide? Cell Cycle 5:812-817, 2006

121. Pantel K, Cote RJ, Fodstad O: Detection and clinical importance of micrometastatic disease. J Natl Cancer Inst 91:1113-1124, 1999 
122. Wiedswang G, Borgen E, Schirmer $C$ et al: Comparison of the clinical significance of occult tumor cells in blood and bone marrow in breast cancer. Int J Cancer 118:2013-2019, 2006

123. Bidard FC, Mathiot $C$, Delaloge $S$ et al: Single circulating tumor cell detection and overall survival in nonmetastatic breast cancer. Ann Oncol 21:729-733, 2010

124. Bidard FC, Vincent-Salomon A, Sigal-Zafrani B et al: Prognosis of women with stage IV breast cancer depends on detection of circulating tumor cells rather than disseminated tumor cells. Ann Oncol 19:496-500, 2008

125. Schmidt-Kittler O, Ragg T, Daskalakis A et al: From latent disseminated cells to overt metastasis: genetic analysis of systemic breast cancer progression. Proc Natl Acad Sci U S A 100:7737-7742, 2003

126. Schardt JA, Meyer M, Hartmann $\mathrm{CH}$ et al: Genomic analysis of single cytokeratin-positive cells from bone marrow reveals early mutational events in breast cancer. Cancer Cell 8:227-239, 2005

127. Theodoropoulos PA, Polioudaki H, Agelaki S et al: Circulating tumor cells with a putative stem cell phenotype in peripheral blood of patients with breast cancer. Cancer Lett 288:99-106, 2010

128. Liu S, Wicha MS: Targeting breast cancer stem cells. J Clin Oncol 28:40064012, 2010

129. McDermott SP, Wicha MS: Targeting breast cancer stem cells. Mol Oncol 2010 
130. Kakarala M, Wicha MS: Implications of the cancer stem-cell hypothesis for breast cancer prevention and therapy. J Clin Oncol 26:2813-2820, 2008

Tab. 1: Diagnostic accuracy of FDG-PET in staging axillary nodes. Summarized results of a meta-analysis [20].

\begin{tabular}{|l|c|c|c|c|c|}
\hline $\begin{array}{c}\text { Quality of } \\
\text { Study* }\end{array}$ & $\begin{array}{c}\text { Number } \\
\text { of Studies } \\
\text { / Pts. }\end{array}$ & $\begin{array}{c}\text { Sensitivity } \\
(\%)\end{array}$ & $\begin{array}{c}\text { Specificity } \\
(\%)\end{array}$ & $\begin{array}{c}\text { Positive } \\
\text { Predictive } \\
\text { Value (\%) }\end{array}$ & $\begin{array}{c}\text { Negative } \\
\text { Predictive } \\
\text { Value (\%) }\end{array}$ \\
\hline A (best) & $3 / 675$ & 78 & 85 & 80 & 84 \\
\hline B & $4 / 222$ & 67 & 89 & 82 & 78 \\
\hline C & $8 / 207$ & 96 & 84 & 78 & 97 \\
\hline D (poor) & $6 / 167$ & 78 & 99 & 99 & 76 \\
\hline
\end{tabular}

${ }^{*}$ depending on number and selection of patients, technical details of examination, pro- or retrospective design, method of lymph node biopsy.

Tab. 2: Diagnostic accuracy of MRI in staging axillary nodes.

\begin{tabular}{|l|c|c|c|c|c|}
\hline Author & $\begin{array}{c}\text { Number } \\
\text { of pts. }\end{array}$ & $\begin{array}{c}\text { Sensitivity } \\
(\%)\end{array}$ & $\begin{array}{c}\text { Specificity } \\
(\%)\end{array}$ & $\begin{array}{c}\text { Positive Predictive } \\
\text { Value (\%) }\end{array}$ & $\begin{array}{c}\text { Negative Predictive } \\
\text { Value (\%) }\end{array}$ \\
\hline $\begin{array}{l}\text { Harada (2007) } \\
{[24]}\end{array}$ & 33 & 86 & 97 & 91 & 96 \\
\hline $\begin{array}{l}\text { Stadnik (2006) } \\
\text { [25] }\end{array}$ & 10 & 100 & 80 & 80 & 100 \\
\hline $\begin{array}{l}\text { Murray (2002) } \\
{[26]}\end{array}$ & 47 & 100 & 56 & 38 & 100 \\
\hline $\begin{array}{l}\text { Michel (2002) } \\
\text { [27] }\end{array}$ & 20 & 82 & 100 & 100 & - \\
\hline $\begin{array}{l}\text { Memarsadeqhi } \\
\text { (2006) [28] }\end{array}$ & 22 & 100 & 98 & $98 \%$ accuracy \\
\hline $\begin{array}{l}\text { Suzuma } \\
\text { (2002) [29] }\end{array}$ & 62 & 91 & 100 & \multicolumn{2}{|c|}{$91 \%$ accuracy } \\
\hline $\begin{array}{l}\text { Stets } \\
(2002)[30]\end{array}$ & 9 & 63 & 86 & \multicolumn{2}{|c|}{$75 \%$ accuracy } \\
\hline
\end{tabular}


Tab. 3: Reasons for and against knowledge of lymph node status for treatment decisions.

\begin{tabular}{|c|c|}
\hline Contra & Pro \\
\hline $\begin{array}{l}\text { - Tumor biology is more important than } \\
\text { nodal status regarding prognosis and } \\
\text { treatment }\end{array}$ & $\begin{array}{l}\text { - Treatment mismatch if node status is } \\
\text { unknown (especially in ER-positive, } \\
\text { HER2-negative disease) }\end{array}$ \\
\hline $\begin{array}{l}\text { - Any axillary surgery increases costs } \\
\text { and morbidity }\end{array}$ & \multirow[t]{2}{*}{$\begin{array}{l}\text { - dose-dense and/or dose-intense } \\
\text { chemotherapy in patients with } 4 \text { or more } \\
\text { involved lymph nodes }\end{array}$} \\
\hline $\begin{array}{l}\text { - Axillary recurrences are very seldom, } \\
\text { even in node positive patients }\end{array}$ & \\
\hline \multirow{3}{*}{$\begin{array}{l}\text { - Delayed surgery of involved lymph } \\
\text { nodes is without overall survival } \\
\text { disadvantages }\end{array}$} & $\begin{array}{l}\text { - Resection of metastases as a potential } \\
\text { source of distant metastases }\end{array}$ \\
\hline & - Tumor volume reduction \\
\hline & \multirow{2}{*}{$\begin{array}{l}\text { - Nodal status as an indicator for or } \\
\text { against radiotherapy after mastectomy }\end{array}$} \\
\hline - Distant metastasis even in pNO patients & \\
\hline $\begin{array}{l}\text { - Seldom axillary metastases in patients } \\
\text { with medial tumor location, }\end{array}$ & \multirow[t]{4}{*}{$\begin{array}{l}\text { - pN for staging, study inclusion and } \\
\text { comparison of outcome necessary }\end{array}$} \\
\hline $\begin{array}{l}\text { - Systemic treatment acts also in axillary } \\
\text { lymph node metastases }\end{array}$ & \\
\hline $\begin{array}{l}\text { There is no evidence that lymph node } \\
\text { metastases are able to metastasize }\end{array}$ & \\
\hline $\begin{array}{l}\text { - Leaving involved lymph nodes in situ } \\
\text { does not increase axillary recurrences } \\
\text { or metastasis }\end{array}$ & \\
\hline
\end{tabular}

Tab. 4: Prospective randomized clinical trials comparing axillary lymph node dissection versus no axillary surgery. Veronesi et al. randomized patients with no axillary surgery to none further treatment versus radiotherapy of the axilla.

\begin{tabular}{|c|c|c|c|c|c|c|}
\hline & Pts. & $\mathrm{N}$ & $\begin{array}{l}\text { Follow } \\
\text {-up (mo) }\end{array}$ & $\begin{array}{l}\text { Axillary } \\
\text { recurrences }\end{array}$ & DFS & OAS \\
\hline $\begin{array}{l}\text { Rudenstam } \\
\text { (2006) [54] }\end{array}$ & $\begin{array}{c}>60 \mathrm{y}, \mathrm{pT} 1-2^{*} \\
\text { cNo, }\end{array}$ & 473 & 78 & 0.9 vs $2.5 \%$ & $\begin{array}{c}67 \% \text { vs } 66 \% \\
p=.7\end{array}$ & $\begin{array}{c}75 \% \text { vs } 73 \% \\
p=.8\end{array}$ \\
\hline \begin{tabular}{|l|} 
Martelli \\
$(2005)$ [55]
\end{tabular} & $\begin{array}{l}>65 \mathrm{y}, \mathrm{pT} 1 \\
\mathrm{cN0} \text {, Tam }\end{array}$ & 219 & 60 & 0 vs $1.8 \%$ & $\begin{array}{c}95 \% \text { both } \\
p=.9\end{array}$ & $\begin{array}{c}96 \% \text { both } \\
p=.9\end{array}$ \\
\hline \begin{tabular}{|l} 
Veronesi \\
(2005) [56]
\end{tabular} & $\begin{array}{l}>45 \mathrm{y}, \text { Tumor } \\
<1.2 \mathrm{~cm}, \mathrm{cN} 0\end{array}$ & 435 & 63 & 0.5 vs $1.5 \%$ & $\begin{array}{c}97 \text { vs } 95 \% \\
p=.19\end{array}$ & $\begin{array}{c}99 \text { vs } 97 \% \\
p=.23\end{array}$ \\
\hline
\end{tabular}

${ }^{*} 42 \%$ pts. with tumors $>2 \mathrm{~cm}, \mathrm{y}=$ years, $\mathrm{mo}=$ months

DFS = disease-free survival

OAS $=$ overall survival 
Tab. 5: Summary of studies reporting outcome (follow-up $>24$ months) of patients (case numbers $\geq 150$ ) with isolated tumor cells pNO(i+) and micrometastasis pN1mi (International Union Against Cancer classification, >.2 mm to $\leq 2.0 \mathrm{~mm}$ ) in sentinel lymph node (SLN)

\begin{tabular}{|c|c|c|c|c|c|}
\hline Author & Study design & Accrual period & $\mathbf{N}$ & Follow-up & \\
\hline $\begin{array}{l}\text { Weaver } \\
(2011) \\
{[96]}\end{array}$ & $\begin{array}{l}\text { prospective, } \\
\text { multicenter }\end{array}$ & 1999-2004 & 3,887 & $95.6 \mathrm{mo}$ & $\begin{array}{l}\text { Occult metastases } \\
\text { pN1a) in initial nega } \\
\text { significant impact o }\end{array}$ \\
\hline $\begin{array}{l}\text { Maaskant-Braat } \\
(2011) \text { [97] }\end{array}$ & population-based & 1996-2006 & 6,803 & $\begin{array}{c}50 \mathrm{mo}, \\
36 \mathrm{mo} \text { for } \\
\text { pNO(i+) }\end{array}$ & $\begin{array}{l}\text { pN1mi or pNO(i+) ir } \\
\text { significant OAS diff } \\
\text { (discrimination betv }\end{array}$ \\
\hline $\begin{array}{l}\text { Langer } \\
(2009)[80]\end{array}$ & prospective cohort & $1998-2002$ & 150 & $77 \mathrm{mo}$ & $\begin{array}{l}\text { No significant differe } \\
\text { between pN0 and pN }\end{array}$ \\
\hline \begin{tabular}{|l} 
de Boer \\
(2009) [89]
\end{tabular} & population-based & before 2006 & 2,707 & $5.1 \mathrm{y}$ & $\begin{array}{l}\mathrm{pN}(\mathrm{i}+) \text { and } \mathrm{pN} 1 \mathrm{mi} \\
5 \mathrm{y}-\mathrm{DFS} \text { in cases wi }\end{array}$ \\
\hline \begin{tabular}{|l} 
Montagna \\
(2009) [98]
\end{tabular} & prospective cohort & 1997-2002 & 3,158 & $6.3 \mathrm{y}$ & $\begin{array}{l}\text { Among SLNB group } \\
\text { pts. with pN0 or min } \\
\text { micrometastasis } 0.2\end{array}$ \\
\hline \begin{tabular}{|l|} 
Reed \\
(2009) [92]
\end{tabular} & $\begin{array}{l}\text { prospective, } \\
\text { multicenter }\end{array}$ & 1996-2005 & 1,259 & $4.9 \mathrm{y}$ & $\begin{array}{l}\text { pN1mi, but not pN0 } \\
\text { positive nodes }\left(27^{\circ}\right. \\
\text { recurrence rate }\end{array}$ \\
\hline $\begin{array}{l}\text { Gobardhan } \\
(2009)[99]\end{array}$ & prospective cohort & 1999-2007 & 703 & $40 \mathrm{mo}$ & $\begin{array}{l}\text { Risk of distant meta } \\
\text { than in pNO group, } \\
\text { or OAS between pl }\end{array}$ \\
\hline Tan (2008) [86] & retrospective & $1976-1978$ & 368 & $17.6 \mathrm{y}$ & $\begin{array}{l}\text { Clear trend toward } n \\
\text { increasing tumor clu }\end{array}$ \\
\hline $\begin{array}{l}\text { Cox } \\
(2008)[100]\end{array}$ & retrospective review & $1997-2004$ & 2,381 & $1.5-2.1 \mathrm{y}$ & $\begin{array}{l}\text { Poorer OAS/DFS for } \\
\text { pts.; additional axilla } \\
\text { pNO(i+) } \\
\end{array}$ \\
\hline $\begin{array}{l}\text { Nagashima } \\
(2006)[101]\end{array}$ & prospective cohort & $1999-2004$ & 375 & $30 \mathrm{mo}$ & No difference in DN \\
\hline $\begin{array}{l}\text { Imoto (2006) } \\
{[102]}\end{array}$ & retrospective cohort & $1998-2000$ & 165 & $73 \mathrm{mo}$ & $\begin{array}{l}\text { No difference in 6y- } \\
\text { and pN0 pts. }\end{array}$ \\
\hline Fan (2005) [103] & retrospective & 1997-2002 & 390 & $31.1 \mathrm{mo}$ & No difference in $\mathrm{L}$ \\
\hline
\end{tabular}

OAS = Overall survival, DMFS $=$ Distant metastases-free survival, DFS $=$ Disease-free survival; BCSS $=$ Breast cancer-specific survival, pts. $=$ patients; LRR $=$ Local recurrence rate; $\mathrm{mo}=$ months; $\mathrm{y}=$ years; $\mathrm{ITC}=$ isolated tumor cells 